\title{
First Report of Yellowing Disease of Banana Leaves Caused by Armillaria Tabescens in Cote d'Ivoire
}

\section{Clovis KNDB ${ }^{1}$, Pauline NDA ${ }^{1}$, Claude $\mathrm{KK}^{1}$, Sylvain $\mathrm{AK}^{1}$ and}

\section{Hortense DA $^{2}$}

${ }^{1}$ University of Jean Lorougnon Guede, Cote d'Ivoire

${ }^{2}$ University of Nangui Abrogoua, Cote d'Ivoire

*Corresponding author: Koffi N'dodo Boni Clovis, Laboratory for Improving Agricultural Production, University of Jean Lorougnon Guede, Daloa, Cote d'Ivoire, Tel: +22548635428; Email: ndomobio@gmail.com

\section{Abstract}

This disease note is the first occurrence of plantain banana leaves yellowing caused by Armillaria tabscens in Côte d'Ivoire. Serious damages of this disease on plantain plants were found in the central area of the country in December 2017.

Keywords: Occurrence; Plantain; Disease; Armillaria Tabescens; Serious

\section{Editorial}

Yellowing disease of banana leaves is commonly attributed to Fusarium oxysporum in Cote d'Ivoire. It's one of the important diseases of plantain banana. Disease incidence was between 21 and 94\% [1]. In 2017, an unknown yellowing disease of banana was observed in the plantain plantation from 1 to 2 years old in the vicinity of Gonate (mid-west Côte d'Ivoire) in a banana regeneration center. Severe yellowing and death of plantain banana were noted (Figure 1).

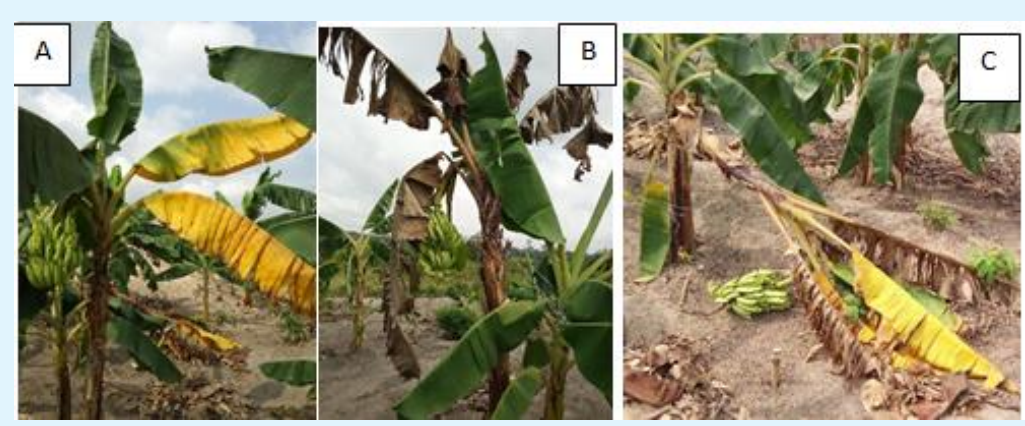

Figure 1: Symptoms of banana yellowing disease on naturally infected plantain leaves.

A: Leaves of plantain showing symptoms of plantain yellowing disease; B: Necrotic leaves of death plant; C: Fall of death plant. 
Disease symptoms were found on both plantation of Gonate plantain regeneration station. 100 plantain bananas were investigated in the first plantation (A). For the second plantation (B), 310 plantain bananas were assessed. Yellowing of banana leaves was recorded weekly in December using systematic monitoring approach. In the first plantation (A), disease index severity ranged from 8.95 to $24.25 \%$ for a period of three weeks. Disease symptoms also progressed from 20.72 to $31.6 \%$ for the same period in plantation B. Disease symptoms development has been described in 6 stages. Initially infected leaves slight yellowing (stage 1) and then $40-50 \%$ of leaves surface turned yellow (stage 2). The stage 3 is reached when 85 to $95 \%$ of leaves surface turned yellow. The fourth stage is characterized by total yellowing of leaves. As the disease progressed, necrotic areas appear on leaves (stage 5). These necrotic areas enlarged and completely cover leaves (stage 6). These necrotic lesions caused death of plantain plants (Figure 1). On each plant, leaves yellowing progressed from external to internal leaves (Figure 1).

Cross section of pseudostem confirmed this observation by necrotic tissues progression from external to internal areas (Figure 2).

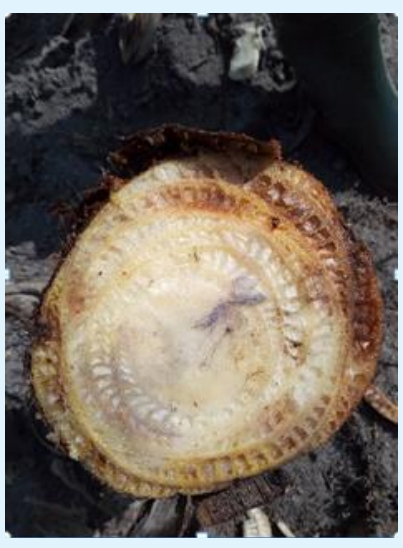

Figure 2: Necrotic tissues of pseudostem.

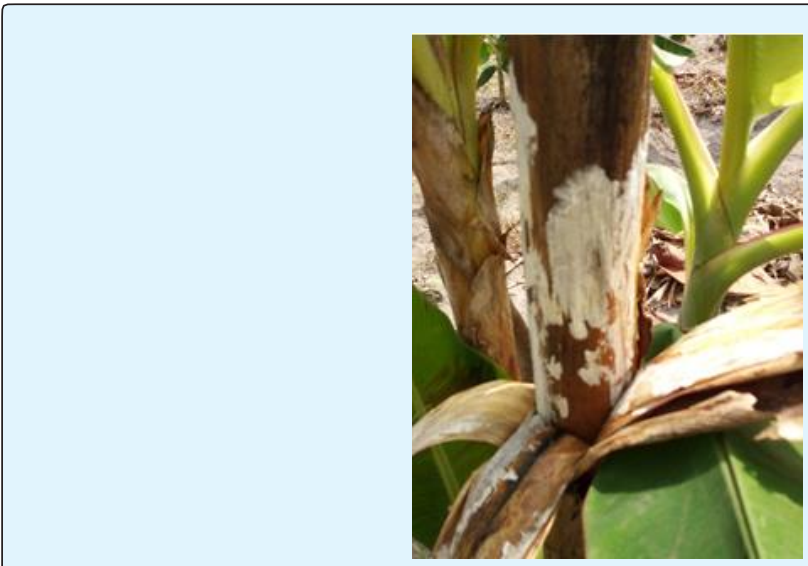

Figure 3: Mycelial mats of Armillaria tabescens under bark of rot pseudostem.

Indeed, white mycelia under bark of pseudostem were also observed on disease plants in both plantations (Figure 3).
Culture of infected tissues on PDA media showed white mycelia. Culture of mycelia on pseudostem after 7-8 weeks showed basidiocarps of Armillaria sp. On 
pseudostem substrate, 30-40 honey color basidiocarps grew. The cap of these basidiocarps was rounded, hollow and funnel-shaped measuring $30-60 \mathrm{~mm}$ in diameter. Gills were white and deccurent. The stems of these mushrooms were also white powdery aspect, $6-10 \mathrm{~cm}$ long and $1-2 \mathrm{~cm}$ wide. Moreover, stems were cylindrical, no hollowed and had no annulus attached just below the gills. Microscopic investigations revealed globose hyaline spores measuring 3.3-6.6x3.3-6.6 $\mu \mathrm{m}$. Morphological and microscopic characteristics described refer to Armillaria tubescens (Figure 4). This description is in line with Tsopelas, et al. [2].
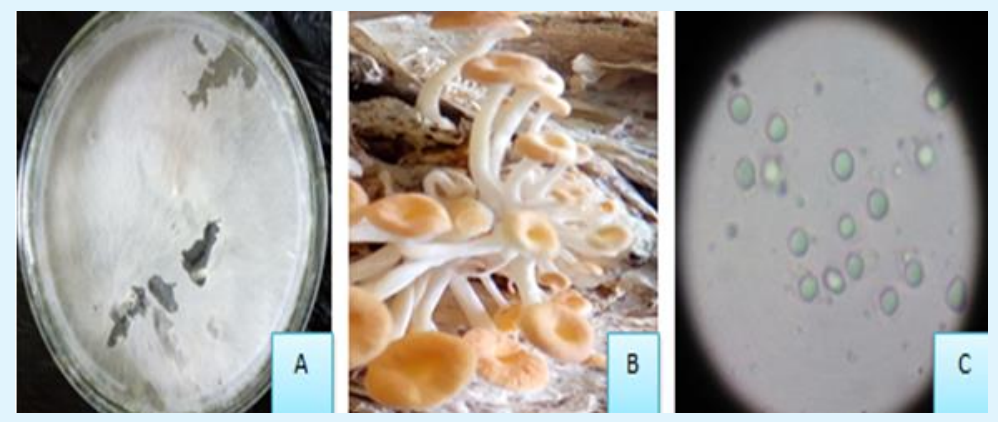

Figure 4: Characteristics of $A$. tabescens cause plantain leaves yellowing disease.

(A) Mycelia on PDA Media; (B) Basidiocarps on Pseudostem Substrat; (C) Micrography of A. tabescens spores. Scale $=6 \mu \mathrm{m}$.

In the inoculation trial, all healthy plantain plants infected with $A$. tabescens showed yellowing symptoms and presence of white rhizomorphs under bark of pseudostem (Figure 5).

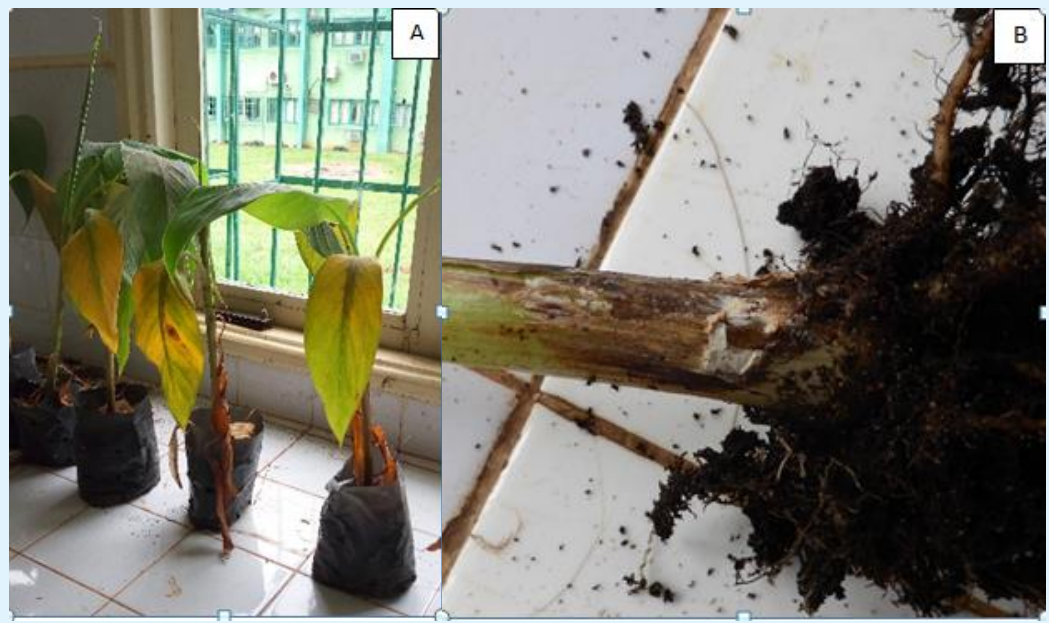

Figure 5: Pathogenicity Test.

(A) Yellowing of plantain seedlings leaves after inoculation of A. Tabescens; (B) Rhizomrphs on seedling's pseudostem.

Armillaria root disease is a wide report on forest and other plantation trees [3]. However, his implication on banana plantain yellowing disease is rarely cited. Thus, this note is the first discovery of banana leaves yellowing caused by $A$. tabescens in Côte d'Ivoire. 


\section{Open Access Journal of Mycology \& Mycological Sciences}

\section{References}

1. Kra KD, Diallo HA, Kobenan K, Kone D, Kouadio YJ (2011) Diagnosis of Fusarium wilt on banana (Musa AAA) and horn 1 (Musa AAB) cultivars on the outskirts of Abidjan District (Ivory Coast). International Journal of Biological and Chemical Sciences 5(4): 1501-1514.
2. Tsopelas P, Tjamos EC (1997) Occurrence a pathogenicity of Armillaria tabescens on almond in Greece. OEPP/EPPO Bulletin 27(4): 455-461.

3. Mamle AM, Jolanda R (2015) Diseases of plantation forestry trees in southern Ghana. International Journal of phytopathology 4(1): 5-13. 